\title{
THE INTEGRATIVE ASPECT OF STUDENTS' INCLUSION IN THE AUTISTIC SPECTRUM ON THE EXAMPLE OF GREEK SCHOOLS
}

\author{
Mizythra Spyridoula \\ Postgraduate Student at the Department of English Philology and Methodics of English Learning \\ Ternopil Volodymyr Hnatiuk National Pedagogical University \\ M. Kryvonosa str., 2, Ternopil, Ukraine \\ orcid.org/0000-0003-0136-2997 \\ roulamizithra1986@yahoo.com
}

Sokol M. O.

Doctor of Pedagogical Sciences,

Professor at the Department of Romanic-German Philology

Ternopil Volodymyr Hnatiuk National Pedagogical University

M. Kryvonosa str., 2, Ternopil, Ukraine

orcid.org/0000-0003-3876-026X

maryanasokol@ukr.net

\section{Key words:}

inclusion, autistic spectrum, pedagogy, special needs.
The inclusion of people with autism is a contentious issue and a challenge for all teachers and community of special education at the international and local level. Although the disability movement has a history of four decades, legislation on the inclusion of people with autism began only a decade ago in some countries and the number of these children in public schools is steadily rising. The integrative aspect of students' inclusion in the autistic spectrum on the example of Greek schools has been outlined in the article. It has been shown that the inclusion of children with autism remains a matter of controversy. The main conditions for the success of children's integration into the autism spectrum has been analyzed in the given research. The success of a program for students' inclusion in the autism spectrum is closely linked to the application of specific criteria, which refer to the knowledge and attitudes of all teachers, the preparation of children in general schools and children with autism, communication between teachers, close school-family communication, appropriate teaching adaptations and continuous evaluation of integration practices. In the field of the autistic spectrum, it has been generally accepted that integration, despite its inherent advantages, is not suitable for all students with autism. It has been noted that an important part of teaching in this area should be about the child's ability to begin contact with other children on his own initiative and his ability to respond to the efforts of peers. Successful educational interventions for the development of social skills in children with autism are numerous and cover the full range of autism. A scientific study has been found that implementing a behavioraltype integration program for a child with preschool autism increased communication initiative, responding to other people's communication initiatives, and building a girl's constructive participation through the use of prompting, positive reinforcement, and individual lesson in another place. In addition, educating a student with Asperger's Syndrome in self-management facilitated the learning of academic and social skills and the reduction of behavioral problems in the general school classroom. 


\title{
ІНТЕГРАТИВНИЙ АСПЕКТ ІНКЛЮЗІЇ УЧНІВ В АУТИСТИЧНОМУ СПЕКТРІ НА ПРИКЛАДІ ГРЕЦЬКИХ ШКІЛ
}

\author{
Мізитра Спирідоула \\ аспірантка кафедри англійської філологї та методики навчання англійської мови \\ Тернопільський національний педагогічний університет імені Володимира Гнатюка \\ вул. М. Кривоноса, 2, Тернопіль, Украӥна \\ orcid.org/0000-0003-0136-2997
}

Сокол М. О.

доктор педагогічних наук, професор кафедри романо-германської філології

Тернопільський національний педагогічний університет імені Володимира Гнатюка
вул. М. Кривоноса, 2, Тернопіль, Україна
orcid.org/0000-0003-3876-026X
maryanasokol@ukr.net

\begin{abstract}
Ключові слова:
інклюзія, аутистичний спектр, педагогіка, особливі потреби.
\end{abstract}

\begin{abstract}
Інклюзія осіб з аутизмом є доволі спірним питанням і викликом для всіх педагогів та громади щодо спеціальної освіти на міжнародному та місцевому рівні. Хоча концепт «інвалідність» уже існує протягом чотирьох десятиліть, однак законодавство в деяких країнах щодо людей з аутизмом розпочало свою роботу лише десять років тому, і кількість цих дітей у державних школах постійно зростає. У статті окреслено інтегративний аспект інклюзії учнів в аутистичному спектрі на прикладі грецьких шкіл. Зазначено, що інклюзія дітей з аутизмом залишається предметом суперечок. Основні умови успішної інтеграції дітей у спектр аутизму проаналізовані в дослідженні. Успіх інклюзійної програми учнів до спектра аутизму тісно пов'язаний із застосуванням конкретних критеріїв, які стосуються знань та ставлень усіх вчителів, підготовки дітей у загальноосвітніх школах та дітей з аутизмом, спілкування між вчителями та ін., тісного спілкування між школою та сім'єю, відповідних методів навчання та постійного оцінювання інтеграційних практик. У галузі аутистичного спектра загальновизнано, що інтеграція, незважаючи на притаманні ій переваги, підходить не для всіх учнів 3 аутизмом. Зазначено, що важлива частина навчання в цій галузі належить здатності дитини налагодити контакт $з$ іншими дітьми за власною ініціативою та його здатності реагувати на поведінку ровесників. Успішні навчальні інтервенції щодо розвитку соціальних навичок у дітей з аутизмом мають бути численними та охоплювати весь спектр аутизму. Досліджено переваги відвідування занять у школі учнів з аутизмом поряд із дітьми 3 типовим розвитком. Зазначено, що характеристики індивідуального розвитку дітей-аутистів суттєво відрізняються в кожному конкретному випадку. Встановлено, що реалізація програми інтеграції типу поведінки для дитини 3 дошкільним аутизмом сприяє комунікативній ініціативі, а спеціальне лікування та корекційне навчання, безумовно, можуть дати поштовх до розвитку аутичної дитини. Доведено, що навчання учнів із синдромом Аспергера в самоуправлінні сприяє засвоєнню академічних та соціальних навичок та зменшенню поведінкових проблем у школі.
\end{abstract}

Problem statement. In Greece, the course of integration of people with disabilities is divided into three phases: the period of hidden or invisible integra- tion (1906-1984), the period of development of special classes (1984-1989) and the period of European influence (1989-2000). Nowadays it is the fourth 
phase of co-education which, although institutionalized and scientifically supported, is not accompanied by structural and substantial changes at the educational practice [14, p. 123].

According to a study of Pedagogical Institute (funded by EPEAEK, scientifically responsible: V. Lambropoulou) it has been found that only $20.23 \%$ of the total number of students with autism in special education schools attend integration departments. Furthermore, the distribution of children with autism who attend integration levels in the three levels of education raises serious concerns, as the largest percentage of these children $(17.04 \%)$ are in primary school integration classes, the lowest percentage (3.19\%) attends kindergarten integration classes, while the percentage of students with autism in secondary education classes is zero [14, p. 124]. The interest has been focused on students with autism who, while starting their schooling in integration classes and preparing to continue their studies in the respective contexts of secondary education, turn to structures of secondary special education. Consequently, the course of their integration is not completed, perpetuating their exclusion from the education system.

An interpretation of this situation has been related to the beliefs and attitudes of teachers in Greece, which are not totally accept school inclusion because they do not have the appropriate training and time to effectively implement inclusion [14, p. 125]. In another recent pan-Hellenic survey of teachers of all levels, it has been found that secondary school teachers chose special education as the best option for children with special needs compared to their peers at other levels [5, p. 379]. In addition, teachers who reported greater acceptance of children with disabilities had a charitable attitude toward these students. In general, the teachers' views were contradictory, as they considered integration necessary to limit stigma and marginalization of children with disabilities, while believing that attending integration classes and special schools is necessary because it offers a safe and protective "shelter" for students with disabilities [5, p. 380].

However, teachers express the need for proper preparation in adapting teaching strategies for people with autism. It is noteworthy that most students with Asperger's syndrome attend integration classes, where teachers have limited experience and training while working with these students. As a result, primary and secondary school teachers had a positive attitude towards integration and expressed the desire for the student with autism to be accompanied by the special educator, without interrupting the structures of parallel support within the general school [6, p. 77]. In addition, the quality of the relationship between general education teachers and children with autism and high functioning autism in the general school is negatively affected by the number of students' behavioral problems [15, p. 123].

The phenomenon of the absence of children with special needs from general secondary education is likely to be an interpretation of the findings on students' attitudes. S. Panteliadou stated that the attitudes of primary school children have been positive towards people with disabilities and their school integration in contrast to adolescents and young people who had the most negative attitude towards students with disabilities and their integration [14, p. 130].

The aim of the article is to outline the integrative aspect of students' inclusion in the autistic spectrum on the example of Greek schools.

The main material of the article. In the field of education, many terms have been used for inclusion with relevant content. The term co-education or education in a single school for all refers to the fact that a child with autism attends a primary school classroom and receives any additional special support needed in that classroom. The term integration refers to the case where the child with autism belongs to the integration department and attends some general school activities [9, p. 411].

The inclusion of children with autism remains a matter of controversy. One concept supports the philosophy that all children have the right to learn and belong to a school for all and community life $[18$, p. 29]. In this ideological context, difference has been recognized as a value and has been linked with the assumption that everyone learns from everyone. Therefore, the school and the wider society accept and appreciate every citizen as an equal member of society, regardless of the differences it may have. The basic hypothesis formulated by the proponents of inclusion was that even simple contact and coexistence of children with autism with peers nonretarded children in the mainstream school environment will be positive in the sense that it would offer multiple learning benefits for students with autism. However, this perception is based more on a perception of values and less on research results.

The other view is more moderate and while accepting the logic of acceptance and inclusion of all children raises the question of the appropriateness and adequacy of each inclusion environment to meet the needs of children with autism. For these educators and academics, the acceptance or rejection of the full integration model as the sole choice for the education of children with autism is based on the findings of empirical research [3, p. 796].

In the field of the autistic spectrum, it is generally accepted that integration, despite its inherent advantages, is not suitable for all students with autism (R. Simpson, B. Myles, J. Burack, R. Root, E. Zigler). The large heterogeneity in the level of abilities of children with autism in many areas of development, 
makes the concept of inclusion very simplistic as a concept and practical approach [11, p. 237]. According to Mesibov and Shea, full integration of students with autism may be restrictive to the options available for their education [11, p. 239]. In addition, after reviewing the literature on the benefits of integration for students with autism and a detailed description of the specific characteristics of people with autism, they conclude that the need to educate children with autism in small and structured learning environments remains. Although it is an expensive educational option.

Such authors like Burack, Root and Zigler (1997) in a critical review of the literature on integration, have been pointed out that the effectiveness of integration programs for autistic children is limited due to significant methodological weaknesses. First of all, in most studies the number of children with autism is small and it is not easy to generalize the results to a larger number of children. Second, many studies are experimental and have not been applied in a natural school environment. Usually the integration framework is not the general school classroom but the kindergarten, the pre-school care centers, the free play in the primary school. Third, the surveys do not include other groups of children to compare results with the intervention group. Fourth, in many experimental studies, the model used is reverse integration (general school children come and participate in special school activities) which is a process contrary to full integration. Fifth, most research involves children with autism and high functioning autism, and the results are not easy to generalize to all children with autism spectrum disorders [3, p. 807].

Research on the benefits of students with autism from joining classes with children with typical development has no common but conflicting findings and raises serious concerns about the acceptance of full integration. First of all, some research has shown that students with autism have significant social benefits from their full inclusion in general school. In particular, they have greater social interaction and support, higher participation in activities, and higher personalized educational goals than children with autism attending special schools. In contrast, preschool children with disabilities have been found to be more likely to experience social rejection $[14$, c. 3]. Another study found that children with autism at school age who attended at least $50 \%$ of the school day in the general class did not differ from normal peers or children with other disabilities in terms of social influence, social preference and participation in a social peer network $[2$, p. 8].

Existing knowledge creates an optimism for the planning of the integration of some children with autism, but it raises serious concerns about the parameters that should be taken into account, so that the process is successful for all students and teachers.
The necessary conditions for the success of children's integration into the autism spectrum process are:

1. Adequate education and cultivation of positive attitudes in teachers of special education, so that they know the special characteristics and educational needs of children with this disability. Knowledge of disability has been found to be associated with the development of a positive attitude towards students with autism. The McGregor and Campbell (2001) found that special education teachers were more positive attitude towards the integration of children with autism compared to teachers of general education, recognizing the disadvantages this would have for all children and stressed that success. However, each integration program is based on each child individually [10, p. 189].

2. Appropriate preparation and ongoing support for general education teachers. The role of the teacher of general education in the social integration of students with autism is catalytic. His contribution to the preparation of children without disabilities and to the organization of teaching conditions is crucial to the success of the child's integration with autism. Teachers who participate in integration programs and have some training in special education have a more positive attitude towards integration as a consequence of their knowledge and active role in this process [1, p. 191].

However, the training and support of the staff should be stable and continuous either in the form of in-school training or in-class training, so that the teaching staff acquires the necessary knowledge about the characteristics and needs of people with autism, integration strategies, as well as collaboration skills with other professionals in the field of education for the design and implementation of educational programs $[17$, p. 116]. Teachers' in-school training facilitates the cultivation of a common philosophy and a common vision that has been found to be the most important factor in designing and implementing school integration.

3. Positive attitude of parents of children with autism. Parents' attitudes are influenced by their child's attendance at an integration context, and the integration process is more successful when supported by parents of children with disabilities. In addition, it seems that the participation of children with autism in integration classes has a positive effect on parents' attitudes towards integration. Parents of children with autism who attend integration classes have been found to have a more positive attitude toward integration than parents of children attending special schools [8, p. 297].

4. Appropriate preparation of students with autism. The success of integration depends largely on the child's social skills with autism and not on the 
degree of his or her disability. The education of children with autism in social skills has been found to be a prerequisite for creating and maintaining social relationships with peers of typical development. The first step in better preparation is to assess the social skills and communication of children with typical development in the context of integration [4, p. 11].

In addition, in order to better adapt to the general school environment, it is important that children with autism are trained in the use of materials used in the general school as well as in the form of help they may have from the teacher, since in the general school they should to be able to work with less supervision. When children with autism have been taught the social skills needed to integrate and have positive social experiences in general school, then the social withdrawal they may show in general school is interpreted as a choice rather than a result of their fear or negative experience with other children [7, p. 104].

To this end, the school integration of children with autism is suggested to follow the following steps to be successful:

a) education of the child with autism in a special environment with special teaching methods;

b) reverse integration, where the children of the general school participate in special context courses;

c) full integration, where children with autism participate in general school after having become familiar with children who participated in the previous stage $[7$, p. 105].

5. Development and cultivation of positive contact and relationships between children with autism and normal children. It is very important to emphasize that the educational framework for the inclusion of a student with a disability should be proportional to his age. When adolescents with severe disabilities are close to school-age children they do not have age-appropriate standards and this environment is restrictive [2, p. 3].

Children with disabilities want to join the culture of peers but experience exclusion from this culture either with obvious rejection or neglect and indifference and teachers should help peers to recognize and respond to the efforts of children with disabilities for contact and interaction at school. However, many studies have found that children have a more positive attitude towards children with physical disabilities than children with mental health problems [12, p. 243].

The teacher can play a key role in cultivating positive attitudes in normal children by properly shaping the natural environment of the classroom and educational materials as well as by encouraging and enhancing positive efforts on the part of children without disabilities. Peers can be the teacher's assistants and the teacher can design special activities aimed at entertainment that help develop social relationships among all children. In a learning environment where the role of the teacher is more guiding and mediating to children, peers respond to the child with autism and the student with autism is well prepared, integration is smoother and more positive for everyone. Reading books for children with disabilities, guided discussions on disability and frequent contact of preschool children with children with disabilities, promote the positive attitude of young children towards children with disabilities.

The inclusion of children in the autism spectrum also has positive effects on the attitudes of normal children. Children who better understand the abilities and difficulties of children with autism are those with the most frequent contact and interaction with children with autism. Children attending kindergartens with other children with disabilities had a more positive attitude than children attending kindergartens without children with special needs. It has also been found that even if children's contact in general school is weekly and covers one year, then children's attitude towards children with severe and profound mental disabilities can remain positive for a period of two years, which demonstrates important role of contact in shaping positive attitudes in children [16, p. 206].

Children with autism may be more easily accepted due to their highly developed gross movement and attractive appearance, which is considered an important criterion for popularity among school-age peers. In addition, it is worth noting that when asked by normal children to encounter children with autism as evidence of altruistic behavior, they responded largely.

6. Appropriate teaching adaptations. For the success of integration programs, all participating staff should be aware of the integration practices that have rich empirical support. Teacher adaptations, student participation in groups that are heterogeneous in terms of skills, collaborative learning and peer learning have been identified as the most important strategies for developing a more effective and appropriate teaching environment for children's integration programs with autism. Students with autism who participated in collaborative learning groups had multiple benefits, as they developed their vocabulary at a faster rate, had greater active participation and social interaction with their peers.

Despite the recognition of the need to implement integration strategies, research on the teaching strategies pursued in the context of integration of students with autism is very limited. In Greece, the ecological observation of 44 general education classes and integration classes showed that the general classroom remains traditional, with frontal teaching, teacher-centered teaching and a complete lack of teaching adaptations, while in the integration department the environment presents a more varied grouping. personalized teaching and active learning [14, p. 130]. 
In addition, the limited number of students in the classroom facilitates the teaching of all students and reduces behavioral problems. A large number of teachers in general education consider that an important condition for the inclusion of a student with a disability is that the number of children be between 15 and 19 students in the classroom.

Another important parameter is the adequacy of time to plan activities for all students. Although collaboration and counseling between special educators and general education teachers is recognized as an important factor in successful integration, teachers themselves report that limited time is a deterrent $[13$, p. 3]. Adequate time is required to design individualized social skills programs and develop alternative teaching methods.

Conclusions. Let's sum up if the interaction context is structured (in terms of space and educational materials) children with autism have many opportunities for social exchanges, even though the typical development children are not systematically trained. However, children's joint activities should follow a routine, even if they are short in duration and frequency. In addition to structured activities, appropriate information for children with typical autism development seems to be a critical factor in the integration of children with autism. It has been found that children who were informed and involved in structured activities with children with autism were more likely to interact with them in the yard.

Children's attitudes toward children with autism appear to be more closely linked to the nature of the disability than to its cause, as they remained negative after watching a short video showing children with autistic behaviors and presenting explanatory information about autism. Still, it seems that strange and unusual behaviors are assessed as more negative than physical disabilities. Children's attitudes improve and remain positive when information is more explanatory and discussion is more frequent, as part of the Friends Circle program. In addition, it has been argued that the most effective way to change children's attitudes toward typical people with autism is when autism is presented as a convincing message from the teacher to the child's parent and contains descriptive, explanatory, and guiding information. However, it is important to emphasize that maintaining social skills in all children is linked to the teacher's attitude. When teachers encourage children with autism and interlocutors to have contact, then social interaction between children is greater. Conversely, when teachers do not monitor and feed peers for their social behavior towards children with autism, then their social relationships with students with autism are weakened.

Since there is not enough empirical support for the full integration of students with autism, our view is that a child's level of integration (degree of integration) is best tailored to each child's needs at each stage of his or her education. Very young children may need more one-on-one systematic teaching after attending a general school. Children with higher functionality may be able to attend a general school classroom and have extra classroom support for their social behavior. Other children with autism may benefit more from part-time attendance in a general school classroom and greater attendance at a special school. Other children with autism can only engage in recreational activities with general school classmates. Age, cognitive level, behavioral problems, and social awareness are important criteria for planning an integration program for a child with autism.

\section{References}

1. Avramidis E., Bayliss P., Burden R. (2000) A survey into mainstream teachers' attitudes towards the inclusion of children with special ed. needs in the ordinary school in one local education authority. Educational Psychology. Athens: Star Co, pp. 191-211.

2. Brown L., Wilcox B. (2004) Toward the realization of the least restrictive environments for severely handicapped students. Research and Practice for Persons with Severe Disabilities. Boston: Publishing House, pp. 2-8.

3. Burack J.A., Root R., Zigler E. (1997) Inclusive education for students with autism: Reviewing ideological, empirical, and community considerations. Handbook of autism and pervasive new developmental disorders (2nd ed.). New York: Wiley, pp. 796-807.

4. Gena A., Kymissis E. (2001) Assessing and setting goals for the attending and communicative behaviour of three preschoolers with autism in inclusive kindergarten settings. Journal of Developmental and Physical Disabilities. Pp. 11-26. URL: https://academic-accelerator.com/Impact-Factor-IF/Journal-of-Developmental-and-Physical-Disabilities

5. Zoniou-Sideri A., Vlachou A. (2006) Greek teachers' belief systems about disability and inclusive education. Intern. The International Journal of Inclusive Education. UK: Taylor and Francis, pp. 379-394.

6. Idol L. (2006) Toward inclusion of special education students in general education. Remedial and Special Education. Kansas: SAGE, pp. 77-94.

7. Jordan R. (2005) Managing autism and Asperger in current educational system. Pediatric Rehabilitation. Athens: PTU, pp. 104-112. 
8. Kasari C., Freeman S.F.N., Bauminger N., Alkin M.C. (1999) Parental perspectives on inclusion: Effects of autism and Down syndrome. Journal of Autism and Developmental Disorders. Berlin: Springer Science and media, pp. 297-305.

9. Kranz P.J. (2000) Commentary: Interventions to facilitate socialization. Journal of Autism and Developmental Disorders. Berlin: Springer Science and media, pp. 411-413.

10. McGregor E., \& Campbell E. (2001). The attitudes of teachers in Scotland to the integration of children with autism into mainstream schools. Scotland: Press TA, pp. 189-207.

11. Mesibov G.B., Shea V. (1996) Full inclusion and students with autism. Journal of Autism and Developmental Disorders. Berlin: Springer Science and media, pp. 337-346.

12. Nowicki E.A., Sandieson P. (2002) A meta-analysis of school-age children's attitudes towards persons with phys. or intellectual disabilities. Warsaw: CooLTd, pp. 243-265.

13. Odom S.L., Diamond K.E. (1998) Inclusion of young children with special needs in early childhood education: The research base. Early Childhood Research Quarterly. New York: Social publishing house, pp. 3-25.

14. Panteliadou S., Lambropoulou V. (2000). Adolescents and young people: Attitudes towards students with special needs and their school integration. London: New Education, pp. 120-133.

15. Robertson K., Chamberlain B., Kasari C. (2003) General education teachers' relationships with included students with autism. Journal of Autism and Developmental Disorders. Berlin: Springer Science and media, pp. 123-130.

16. Shevlin, M., O’Moore A.M. (2000) Fostering positive attitudes: reactions of mainstream pupils to contact with their counterparts who have severe/profound intellectual disabilities. European Journal of Special Needs Education, pp. 206-217. URL: https://www.tandfonline.com/toc/rejs20/current

17. Simpson R.L., de Boer-Ott S., Myles B.S. (2003) Inclusion of learners with autism spectrum disorders in general education settings. Topics in Language Disorders. Harward: Meta Press, pp. 116-133.

18. Stainback S., Stainback W. (1992). Schools as inclusive communities. In Controversial issues confronting special education. Boston: Allyn, Bacon, pp. 29-43. 